\title{
What is the relationship between the coronavirus crisis and air pollution in Tunisia?
}

\author{
Nihel Chekir ${ }^{1}\left[\right.$ Yassine Ben Salem $^{1}$ (i)
}

Received: 15 April 2020 / Accepted: 23 July 2020 / Published online: 4 November 2020

(c) The Author(s) 2020

\begin{abstract}
Since the beginning of 2020, the COVID-19 pandemic has generated horror and panic around the world. Nevertheless, this terrible crisis is having a positive side effect: it is lowering pollution levels. The outbreak of the coronavirus has caused many governments to impose measures to slow the spread of the virus within populations, such as limiting population displacement, requesting social distancing and the isolation of individuals at home, and reducing industrial activity. In this work, we investigated the effects of governmental measures taken to limit the spread of COVID-19 on the concentrations of air pollutants over four Tunisian cities (Tunis, Sousse, Sfax, and Tataouine). Data on the average daily levels of nitrogen dioxide, sulfur dioxide, carbon monoxide, and particulate matter during January, February, March, and April of 2020 were collected, treated, and analyzed for each city. Curves of average monthly pollutant concentrations from 1 January to 30 April for each city investigated showed that measures taken to reduce the spread of the virus had a substantial impact on emission levels: there were tremendous drops of $51 \%$ in $\mathrm{NO}_{2}$ and $52 \%$ in $\mathrm{SO}_{2}$ over Sfax City during March compared to those during January, while nitrogen dioxide and sulfur dioxide levels dropped by about $38 \%$ and $42 \%$, respectively, over Tunis City and by around $20 \%$ for Sousse. During the four months investigated, almost all of the pollutant concentrations showed a significant drop from mid-March. On 12 March, the Tunisian government imposed some individual and collective measures to protect the population from the virus, such as social distancing, limiting transportation, shutting down schools and universities, and reducing industrial activity. A general lockdown was brought in later. Thus, restricting human and industrial activities appeared to affect the air quality in Tunisia, leading to a marked improvement in the air quality index.
\end{abstract}

\section{Graphic abstract}

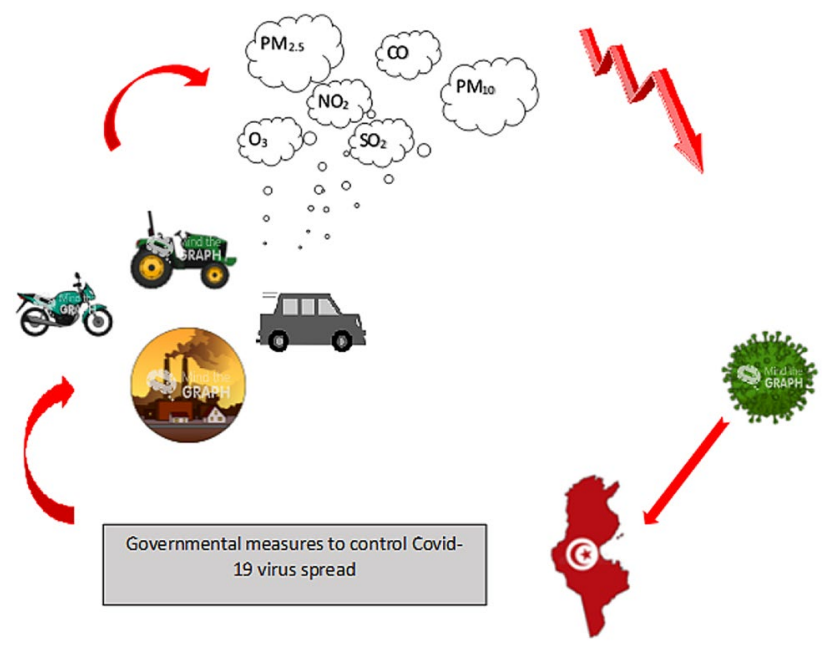

Keywords COVID-19 $\cdot$ Tunisia $\cdot$ Air pollution $\cdot$ Lockdown $\cdot$ Environment $\cdot$ Gas emissions

Communicated by Mohamed Ksibi, Co-Editor in Chief.

Extended author information available on the last page of the article 


$\begin{array}{ll}\text { Abbreviations } \\ \mathrm{AQI} & \text { Air quality index } \\ \mathrm{CO} & \text { Carbon monoxide } \\ \mathrm{COVID} & \text { Coronavirus disease } \\ \mathrm{EPA} & \text { Environmental Protection Agency } \\ \mathrm{ICT} & \text { Information and communication technology } \\ \mathrm{MERS} & \text { Middle East respiratory syndrome } \\ \mathrm{NASA} & \text { National Aeronautics and Space Administration } \\ \mathrm{NO}_{2} & \text { Nitrogen dioxide } \\ \mathrm{PM} & \text { Particulate matter } \\ \mathrm{SARS} & \text { Severe acute respiratory syndrome } \\ \mathrm{SO}_{2} & \text { Sulfur dioxide } \\ \mathrm{STEG} & \text { Tunisian Electricity and Gas Company } \\ \text { VOC } & \text { Volatile organic compounds } \\ \text { WHO } & \text { World Health Organization }\end{array}$

\section{Introduction}

As of 30 April 2020, the novel coronavirus SARS-CoV-2, which originated in China in late December 2019, was reported to have infected 3,266,132 people around the world and killed almost 234,000 since the start of the COVID-19 (COronaVIrus Disease 2019) pandemic (Worldmeters 2020). This pandemic has affected almost all countries, although it is most prevalent in America, followed by Europe, Asia, and the Middle East. For instance, by 30 April 2020, there had been at least 994 confirmed cases of the novel coronavirus in Tunisia, including 41 deaths (Worldmeters 2020).

The World Health Organization (WHO) has warned countries that the COVID-19 pandemic requires urgent action. Moreover, they have been preparing for the worstcase scenario as the total number of virus infections has increased. This scenario, as reported by a former chair of the Global Health Council and a long-term collaborator with the World Health Organization (WHO) (Spinney 2020), is that the outbreak goes global and the disease eventually becomes endemic, meaning that it circulates permanently in the human population.

Due to the recent rapid emergence of the global COVID19 pandemic, the World Health Organization has proposed emergency measures that aim to reduce virus transmission rates and contamination. These measures consist of limiting population movement and travel, strict social distancing, the isolation of individuals at home, and even, if necessary, a general population lockdown (Lai 2020). While this suppression of human activity has many negative effects, it is a critically important way of limiting the spread and impact of COVID-19 (Coccia 2020). On the other hand, the marked reduction in human activity caused by these measures appears to have coincided with an improvement in the air quality in cities, so this substantial change in human behavior is thought to have altered air pollution levels ( $\mathrm{He}$ 2020; Cadotte 2020).

During the second half of March 2020, gas emissions over China dropped by a quarter as cars, trucks, power plants, and factories ground to a halt. The same phenomenon was seen in California (which is known to have very high levels of air pollution), as shown by images taken by NASA's Earthobserving satellite. Scientists predict that global carbon dioxide emissions could drop by more than $5 \%$ in 2020 , which would represent the first decrease in carbon dioxide emissions since the 2008 economic crisis (when it fell by $1.4 \%$ ), and the most significant fall during the past 50 years (Reuters 2020). Satellite images have highlighted noticeably decreased levels of nitrogen dioxide in large industrial cities and regions in Europe (e.g., Brussels, Paris, Madrid, Milan, Frankfurt, and northern Italy) during the period 5-25 March 2020 as compared to the same period in 2019 (Wood 2020).

Industrialization and increasing numbers of vehicles are worsening levels of air pollution around the world. In fact, the air has become so polluted that it can no longer be cleaned up by natural processes (IQAir 2020). The Environmental Protection Agency (EPA) has defined the six main contributors to air pollution (EPA 2014): ground-level ozone $\left(\mathrm{O}_{3}\right)$, particle pollution, lead, nitrogen dioxide $\left(\mathrm{NO}_{2}\right)$, carbon monoxide $(\mathrm{CO})$, and sulfur dioxide $\left(\mathrm{SO}_{2}\right)$. These air pollutants, which are considered to be critical emissions, are found in urban areas and released into the atmosphere at concentrations high enough to gradually induce severe health problems (EPA 2010).

Air pollution affects human health in many different ways (Sanità 2020). Exposure to high levels of air pollutants for a short period can produce short-term health effects that mainly affect the eyes, throat, nose, and upper respiratory system, causing asthma, emphysema, pneumonia, and bronchitis. Other symptoms include nausea, headache, and allergies. On the other hand, exposure to low levels of air pollutants over a long period can lead to long-term effects such as heart disease, lung cancer, chronic respiratory disease, and even damage to the brain, liver, nerves, or kidneys.

Recent scientific studies conducted in some countries and cities have examined the effects of the COVID pandemic on air pollution (Anjum 2020). Improvements in air quality were observed in China (He 2020), Italy (Lippi 2020), England (Travaglio 2020), Brazil (Nakada 2020; Dantas 2020), Kazakhstan (Kerimray 2020), India (Sharma 2020), and worldwide (Shrestha 2020).

In the present study, we investigated how the levels of six air pollutants in four Tunisian cities varied during January, February, March, and April 2020 to probe the effects of the COVID-19 pandemic crisis and protection measures imposed by the Tunisian government, including the lockdown. These cities have different characteristics in terms of their urban/rural nature, traffic levels, and residential/ 
industrial character. We collected, treated, and analyzed freely available air monitoring data for the selected cities to assess the impact of the coronavirus outbreak on urban air pollution.

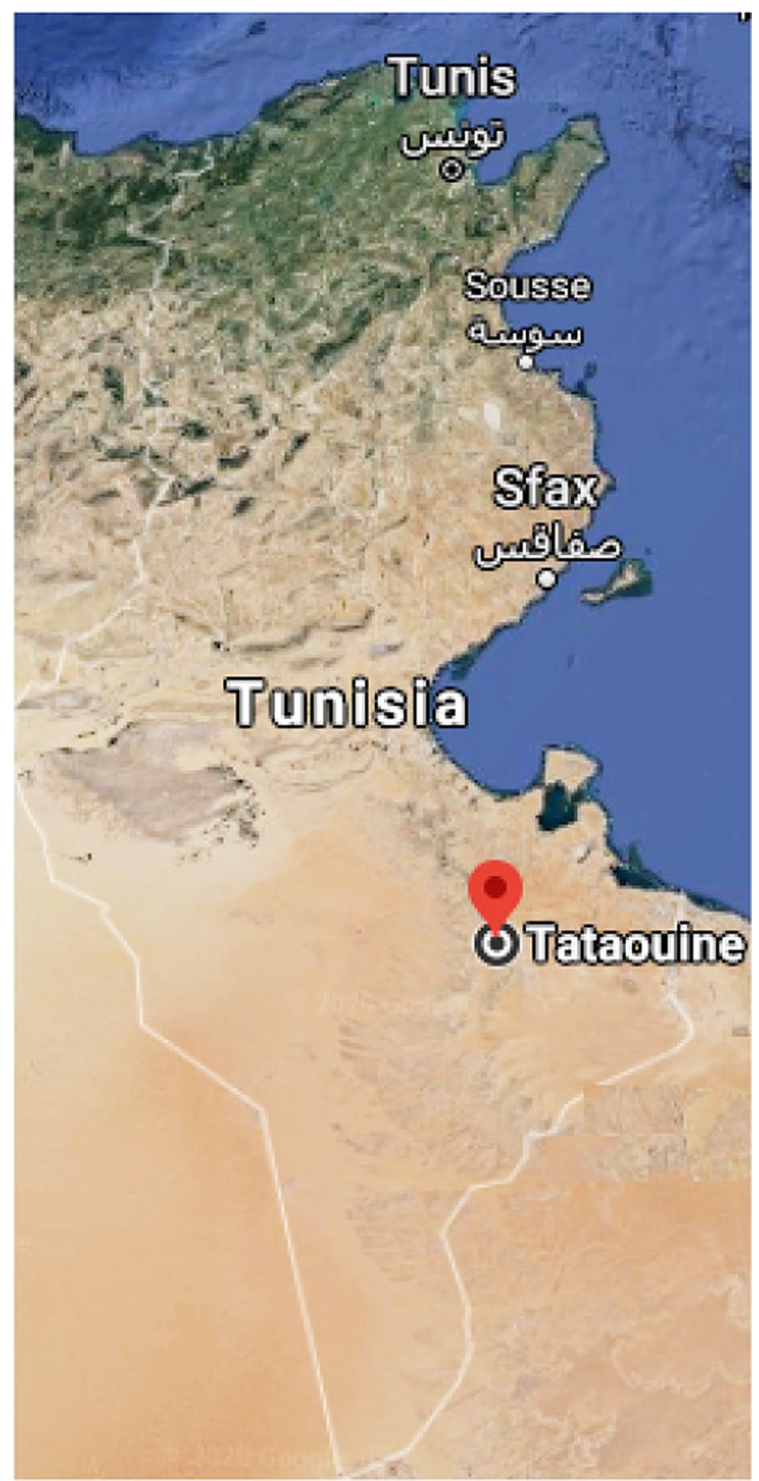

Fig. 1 Locations of the four Tunisian cities investigated in this work

\section{Data and method}

\section{Investigated cities}

Tunisia is a country in the Maghreb region of North Africa that covers 163,610 square kilometers and had a population of 11.582 million in 2018 (World Bank 2020). Four Tunisian cities that were affected by COVID-19 early during the pandemic were selected for this study. The four cities were chosen based mainly on location, economic activity, and population. The cities were the capital Tunis in the north of Tunisia, Sousse and Sfax, both of which are in the center of the country, and Tataouine, which is in southern Tunisia. The map shown in Fig. 1 indicates the locations of the investigated cities.

The four studied cities have different characteristics. Tunis, Sousse, and Sfax are highly populated urban regions with considerable industrial activity (Belhedi 2007). According to the 2014 population census, Tunis (the capital of Tunisia) has the most inhabitants $(1,056,247)$ of any Tunisian city, followed by Sfax and Sousse, which are ranked the second and the fourth largest cities in Tunisia in terms of population, with 955,421 and 674,971 inhabitants, respectively (National Statistics Institute 2014). Another factor taken into consideration in this study was the date of the first confirmed COVID-19 case in the city. The selected cities were infected early during the pandemic (during the period 9-18 March) (Tunisian Ministry of Health 2020). For each city, we collected air pollution data and analyzed pollutant trends before and after the actions taken by the government on 12 March 2020 to contain the spread of the virus. A four-month period was examined: January, February, March, and April 2020. Table 1 lists relevant characteristics of the investigated cities and the dates of the first confirmed infections in those cities.

The main sources of industrial activity in Tunis are ICT, the ecoindustry, aeronautics, and pharmaceuticals. There is also a power plant in Rades, a suburban region of Tunis. Sousse, which is characterized by its mechanical and electronic industries, also has a power plant. Sfax, which is the second most important city in Tunisia from an economic perspective, is known for its chemical industry. The two power plants in Rades and Sousse are owned by the Tunisian

Table 1 Characteristics of the investigated cities (Villeret 2020)

\begin{tabular}{llclll}
\hline City & Urban or rural? & Population in 2014 & $\begin{array}{l}\text { Amount of vehicu- } \\
\text { lar traffic }\end{array}$ & Main economic sector(s) & $\begin{array}{l}\text { Date of the first } \\
\text { confirmed case }\end{array}$ \\
\hline Tunis & Urban & $1,056,247$ & High & Industrial/power plant & 9 March 2020 \\
Sousse & Urban & 674,971 & High & Industrial/power plant/agricultural & 16 March 2020 \\
Sfax & Urban & 955,421 & High & Industrial & 18 March 2020 \\
Tataouine & Urban/rural & 149,453 & Low & Agricultural & 14 March 2020 \\
\hline
\end{tabular}




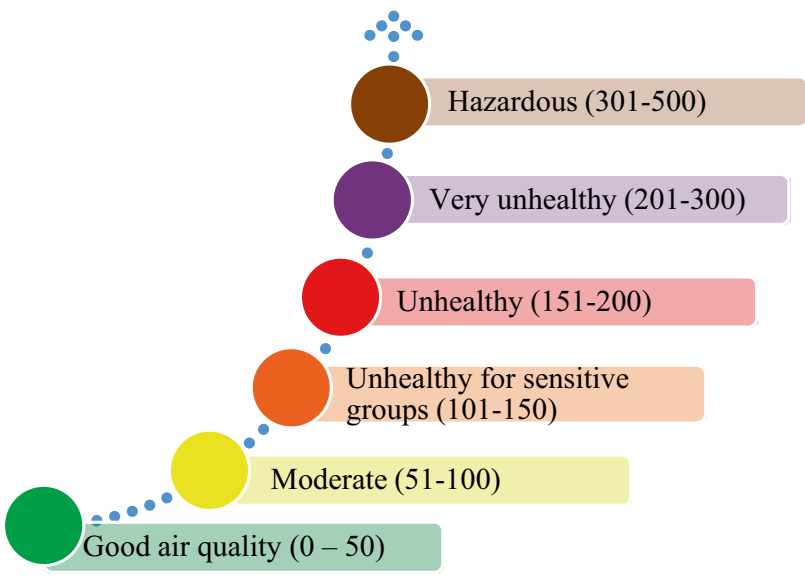

Fig. 2 Air quality index classification according to the EPA

Electricity and Gas Company (STEG), a public company that is charged with the generation and distribution of electricity. As reported in the 2018 STEG Annual Report, electricity is mostly produced by fossil fuel-powered units (94\%) in Tunisia.

\section{Air pollution data collection}

In this study, we collected air quality index (AQI) data and air pollutant concentrations from the Air Matters monitoring platform, a global air quality service provider (www. air-matters.com) that forecasts and provides real-time information on the air quality index, allergenic pollen levels, and weather data. For each investigated city, we downloaded the average daily AQI values and concentrations of the six major air pollutants for the four-month period from 1 January to 30 April 2020. The pollutants considered were fine particulate matter $\left(\mathrm{PM}_{2.5}\right)$, coarse particulate matter $\left(\mathrm{PM}_{10}\right)$, nitrogen dioxide $\left(\mathrm{NO}_{2}\right)$, ground-level ozone $\left(\mathrm{O}_{3}\right)$, sulfur dioxide $\left(\mathrm{SO}_{2}\right)$, and carbon monoxide (CO).

The air quality index (AQI) relates daily pollutant concentrations to health concerns for sensitive groups and the public (EPA 2014). Values below 100 are considered satisfactory. Values above 100 are considered unhealthy-initially for certain sensitive groups of people, and then for everyone as the AQI values increase further. The AQI can range from 0 to 500, and this range is divided into six classes, as shown in Fig. 2.

\section{Data analysis}

For each investigated city, we used the data collected daily to determine the average monthly air quality index and the average monthly concentrations of the six air pollutants for January, February, March, and April 2020.

We assumed that the air quality in January and February 2020 (before the pandemic hit Tunisia) was normal. Therefore, changes in air quality during March and April 2020 were considered to be caused primarily by the actions of the country aimed at containing the spread of COVID-19. We examined Tunisian air pollution for the four first months of 2020 and assessed whether there were linear trends in AQI and pollutant concentration values because of the protection and lockdown measures imposed by the government due to the COVID-19 pandemic. We then compared pre- and postCOVID-19 air quality for the affected cities.

\section{Results}

Plotted average monthly values of $\mathrm{PM}_{2.5}, \mathrm{PM}_{10}, \mathrm{NO}_{2}, \mathrm{O}_{3}$, $\mathrm{SO}_{2}, \mathrm{CO}$, and $\mathrm{AQI}$ for the four chosen Tunisian cities are displayed in Figs. 3, 4, 5, 6, 7, 8, and 9, respectively. We compared the levels of the different air pollutants in January and February to those in March and April, when the COVID-19 protection measures were imposed or in place.

The mean concentrations of almost all the pollutants showed significant reductions in every city following the enactment of COVID-19 protection measures: the curves shown in the figures present substantial differences in pollutant levels between the period before early March 2020 and the period after it.

When the concentrations of $\mathrm{PM}_{2.5}$ during the four months of interest were analyzed (see Fig. 3), we found that there was a slight drop in March compared to January for all of the cities considered except for Tataouine. The observed drops in March as compared to January for Tunis, Sousse, and Sfax were about 20\%, $7 \%$, and 23\%, respectively.

No significant change in $\mathrm{PM}_{10}$ concentration was observed for Tunis, Sousse, and Sfax, while a significant increase was noted for Tataouine (see Fig. 4).

For $\mathrm{NO}_{2}$, the concentration curves for the four cities (see Fig. 5) exhibited decreases in March and April as compared to January and February. Nitrogen dioxide concentrations in March were 37\%, 22\%, and 51\% lower than those in January for Tunis, Sousse, and Sfax, respectively, whereas the $\mathrm{NO}_{2}$ concentration over Tataouine remained constant across the period of interest. As depicted in Figs. 7 and 8, very similar behavior was observed for the levels of $\mathrm{SO}_{2}$ and $\mathrm{CO}$, as decreased concentrations were observed shortly after the restrictions for almost all of the cities. The measured concentration of $\mathrm{SO}_{2}$ in Tunis, Sousse, and Sfax declined by $42 \%, 18 \%$, and $52 \%$, respectively, in March as compared to those in January. The 


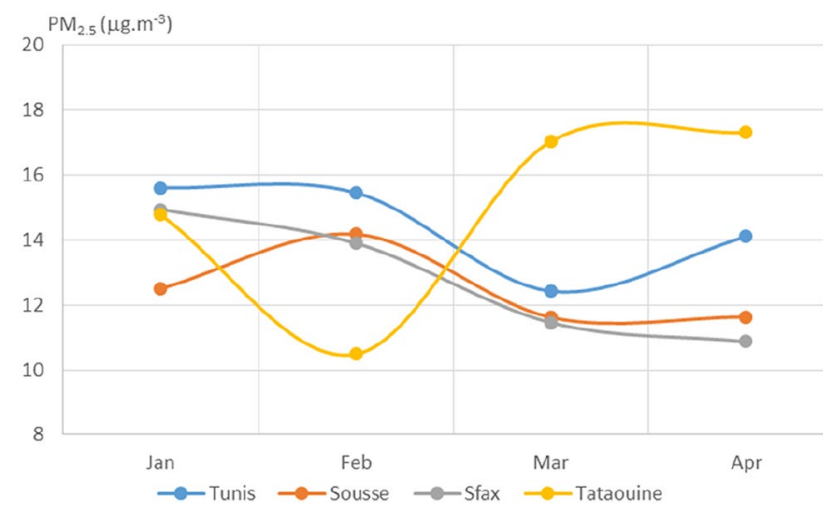

Fig. 3 Monthly average concentrations (in $\mu \mathrm{g} / \mathrm{m}^{3}$ ) of $\mathrm{PM}_{2.5}$

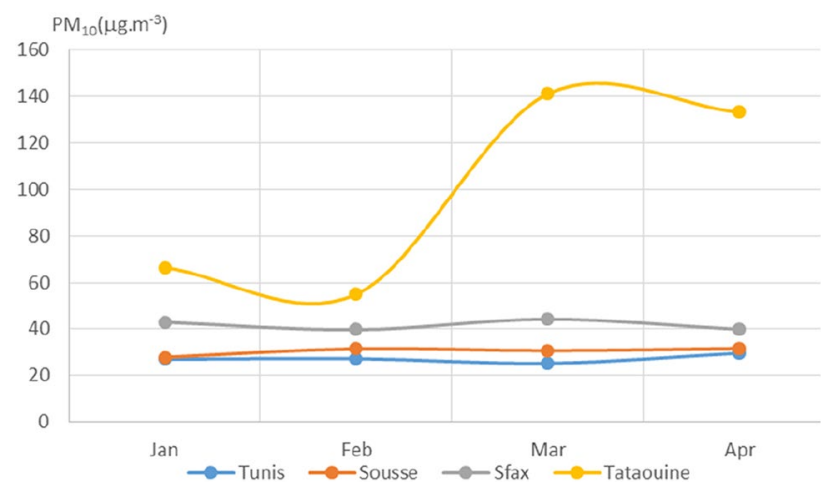

Fig. 4 Monthly average concentrations (in $\mu \mathrm{g} / \mathrm{m}^{3}$ ) of $\mathrm{PM}_{10}$

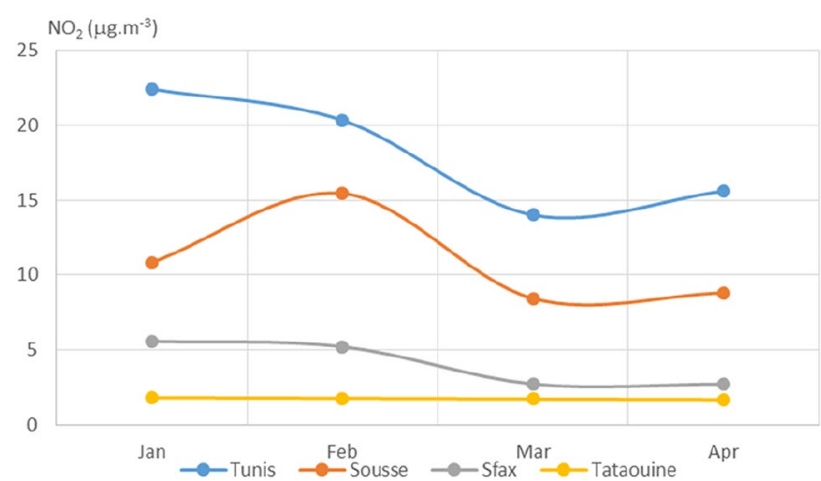

Fig. 5 Monthly average concentrations (in $\mu \mathrm{g} / \mathrm{m}^{3}$ ) of $\mathrm{NO}_{2}$

levels of carbon monoxide declined by around $26 \%, 4 \%$, and $19 \%$ for Tunis, Sousse, and Sfax, respectively.

The protection measures enacted by the government appeared to cause a drop in air pollution, as indicated by the air quality index (see Fig. 9). The AQI dropped by $17 \%, 5 \%$, and $15 \%$ in March as compared to January and

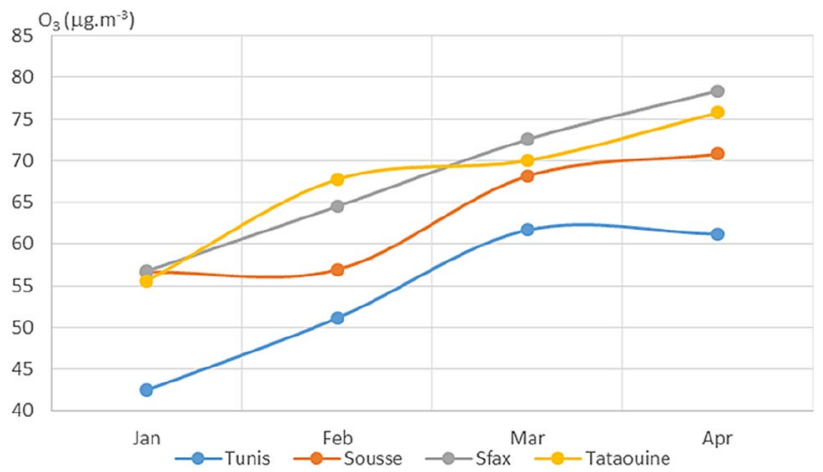

Fig. 6 Monthly average concentrations (in $\mu \mathrm{g} / \mathrm{m}^{3}$ ) of $\mathrm{O}_{3}$

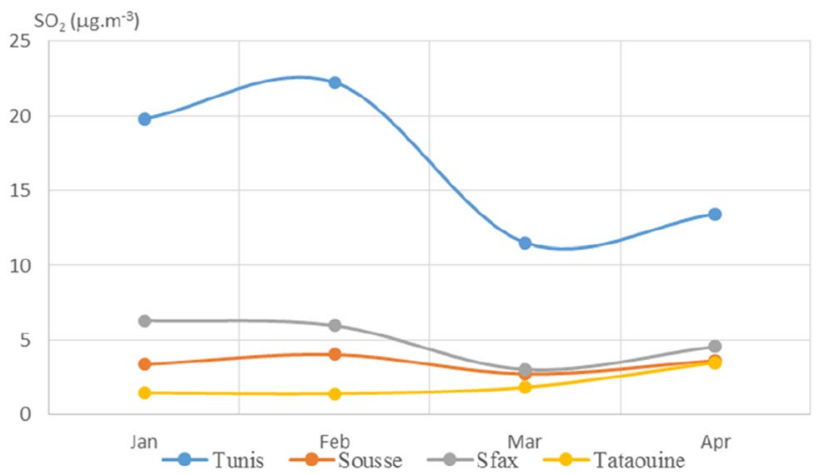

Fig. 7 Monthly average concentrations (in $\mu \mathrm{g} / \mathrm{m}^{3}$ ) of $\mathrm{SO}_{2}$

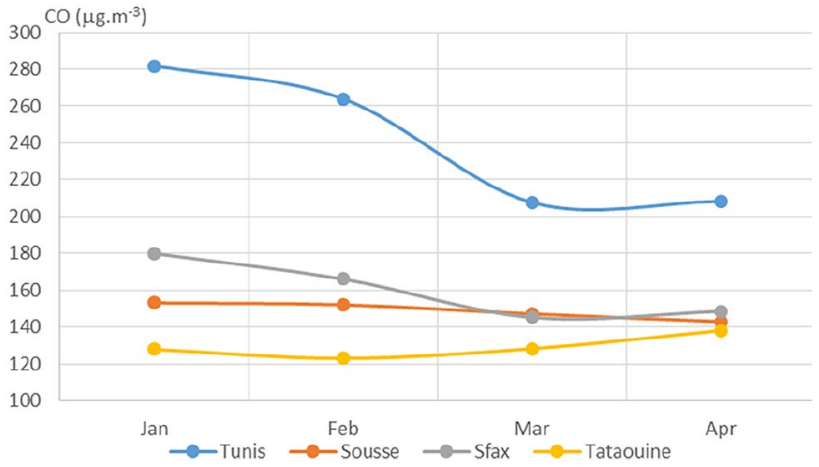

Fig. 8 Monthly average concentrations (in $\mu \mathrm{g} / \mathrm{m}^{3}$ ) of CO

by $6 \%, 3 \%$, and $17 \%$ in April as compared to January for Tunis, Sousse, and Sfax. When compared to the previously mentioned pollutants, ozone showed a late response to the protective measures against COVID-19, which is why the curves shown in Fig. 6 do not follow the same trend as seen for the other pollutants. 


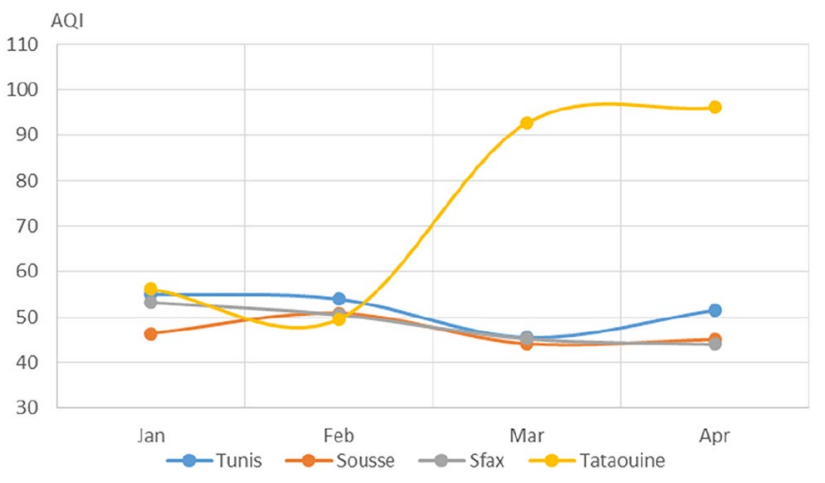

Fig. 9 Monthly average AQI values

\section{Discussion}

From mid-March to the end of April, levels of the pollutants $\mathrm{PM}_{2.5}, \mathrm{NO}_{2}, \mathrm{SO}_{2}$, and $\mathrm{CO}$ as well as AQI values were observed to be substantially lower than those in early January, when power plants and industrial factories were operating at normal levels. The appreciable drop in $\mathrm{PM}_{2.5}$ concentrations can be attributed to the reduction in emissions from vehicular traffic and industrial activity caused by the measures brought in by the Tunisian government to suppress the spread of COVID-19. The increase in $\mathrm{PM}_{2.5}$ concentrations in Tataouine following the introduction of these measures is thought to be due to the meteorological conditions during this time. Tataouine is a pre-Saharan city-a doorway to the desert in southern Tunisia. Storms from the Sahara during the spring months bring a lot of dust, which explains the increased $\mathrm{PM}_{2.5}$ levels observed for March and April.

The remarkable increase in $\mathrm{PM}_{10}$ for Tataouine during March and April (see Fig. 4) can also be explained by the weather conditions. In Tunis, Sousse, and Sfax, large particulates are generally produced through human activity. The relatively constant levels of $\mathrm{PM}_{10}$ in these cities during the monitored period may be due to the long residence time of $\mathrm{PM}_{10}$ in the atmosphere.

For $\mathrm{NO}_{2}, \mathrm{SO}_{2}$, and $\mathrm{CO}$, decreased levels were seen for March and April than for January and February. This appears to have been due to the reduced activities of power plants and other industrial facilities and the restrictions on vehicular use that were imposed from March on to limit the spread of COVID-19. This impact of restrictions due to COVID-19 on pollutant concentrations has been noted in various studies performed in cities around the world (Otmani 2020; Shi 2020; Zhao 2020).

Urbanization and motorization are considered two important sources of congestion. They consume energy and therefore generate pollutant emissions. This explains why the capital Tunis exhibits the highest mean values of the pollutants $\mathrm{SO}_{2}, \mathrm{NO}_{2}, \mathrm{CO}$, and $\mathrm{PM}_{2.5}$.

The only city that showed nonsignificant changes in $\mathrm{NO}_{2}, \mathrm{SO}_{2}$, and $\mathrm{CO}$ concentrations following the introduction of the measures aimed at tackling COVID-19 was Tataouine. The increased concentrations of $\mathrm{O}_{3}$ in all of the cities in March and April can be attributable to the meteorological conditions, because $\mathrm{O}_{3}$ levels tend to rise during spring and summer owing to increased solar radiation (in terms of its intensity and daily duration) (Escudero et al. 2019; Wang et al. 2020). Similar behavior of ozone was observed in Milan (Collivignarelli 2020).

The general air quality improved in March and April, as inferred from the trends in the air quality index (Fig. 9). This general shift in air pollutant concentrations would be expected given that the governmental measures relating to the COVID-19 pandemic were introduced on 12 March. The resulting partial lockdown of the Tunisian population and partial shutdown of industrial activity changed individual and collective behavior. The number of vehicles used dropped dramatically. Moreover, electricity production until 4 April was about 25\% lower than that for the same period in 2019. As can be seen in Figs. 10 and 11 in Appendix A, the demand for electricity and natural gas was also significantly reduced during lockdown and shutdown (Ministère EMTE 2020).

Due to the pandemic, the Tunisian authorities progressively shut down transportation and travel in and out of the country. They also curtailed local business travel, limited local transport, and closed down schools, colleges, and universities to reduce the spread of the disease, as well as establishing numerous quarantine sites in infected areas. Those governmental measures taken in March (limiting transport and shutting down schools on 12 March) rapidly and markedly reduced human movement and activity. The social distancing and almost complete cessation of economic activity caused by the COVID-19 measures led to a significant drop in air pollution over the four investigated towns.

When analyzing the effects of the protection measures and lockdown on the air pollution in the studied cities, we observed that the impact varied depending on the level of industrial activity usually associated with the city.Tataouine, which has an economy that is largely based on agriculture, showed notably different trends in pollutant levels than the other more industrial cities. The concentrations of pollutants in the industrialized cities were more strongly influenced by the COVID-19 measures. Similarly, the air pollution in big cities that usually consume more electricity or suffer from substantial traffic was particularly strongly reduced when the lockdown was implemented. 


\section{Conclusion}

Since 12 March 2020, the Tunisian government has taken a series of protection measures to limit the spread of the novel coronavirus among the Tunisian population. These unique circumstances are perfect for studying the impact of human behavior on air pollution in Tunisia. We carried out the present study to investigate the possible impacts of the COVID-19 human lockdown in Tunisia on air pollution. We utilized average daily air pollutant concentrations collected during air quality monitoring for four cities in Tunisia (Tunis, Sousse, Sfax, and Tataouine). Analysis of the trends in monthly average air pollutant concentrations during the first four months of 2020 showed major drops in $\mathrm{PM}_{2.5}, \mathrm{NO}_{2}$, $\mathrm{SO}_{2}$, and $\mathrm{CO}$ levels from 12 March, when the protection measures were first imposed. A comparison of air quality status between the four Tunisian cities before and after this date revealed that the concentrations of almost all of the pollutants dropped after the measures were introduced. The concentration of $\mathrm{PM}_{2.5}$ reduced over each city except for Tataouine. The concentration of larger particulates $\left(\mathrm{PM}_{10}\right)$ did not change significantly in Tunis, Sousse, and Sfax over the period of interest. However, for Tataouine, the southernmost city, $\mathrm{PM}_{10}$ increased during March and April because of the prevailing meteorological conditions. We also noted marked decreases in the concentrations of nitrogen dioxide, sulfur dioxide, and carbon monoxide in almost all the cities. The largest reduction was observed for the capital Tunis. On the other hand, notable increases in $\mathrm{O}_{3}$ were seen in all the studied cities. The general air quality as assessed using the air quality index appeared to improve in almost all the cities following the introduction of the COVID-19 measures.

Thus, our study shows that the progressive limitation of industrial activity and vehicular traffic and the drop in electric power demand in Tunisia caused by the measures brought in to address the COVID-19 pandemic were accompanied by apparent decreases in air pollution and the air quality index in Tunisian cities. In other words, one side effect of this horrific virus is cleaner Tunisian air.

Funding There was no external funding for this work.

\section{Compliance with ethical standards}

Conflict of interest The authors declare no conflict of interest.

Open Access This article is licensed under a Creative Commons Attribution 4.0 International License, which permits use, sharing, adaptation, distribution and reproduction in any medium or format, as long as you give appropriate credit to the original author(s) and the source, provide a link to the Creative Commons licence, and indicate if changes were made. The images or other third party material in this article are included in the article's Creative Commons licence, unless indicated otherwise in a credit line to the material. If material is not included in the article's Creative Commons licence and your intended use is not permitted by statutory regulation or exceeds the permitted use, you will need to obtain permission directly from the copyright holder. To view a copy of this licence, visit http://creativecommons .org/licenses/by/4.0/.

\section{Appendix A}

See Figs. 10 and 11.

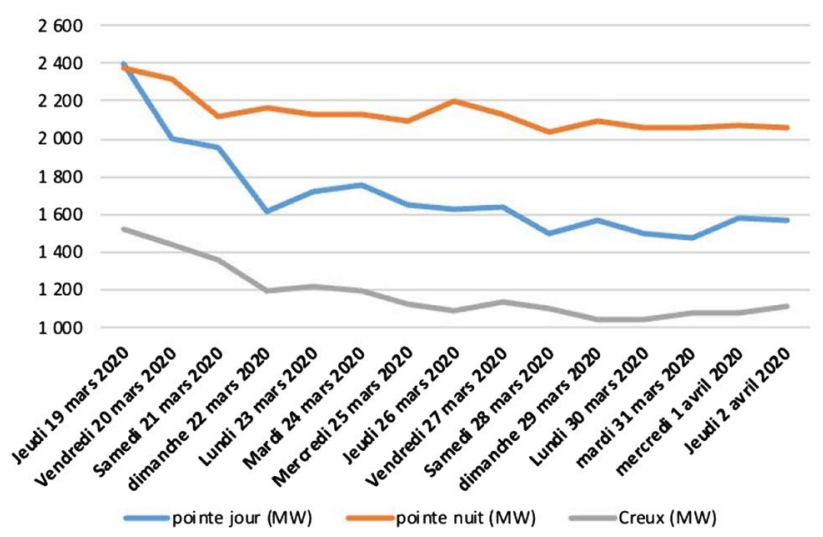

Fig. 10 Electricity demand (MW)

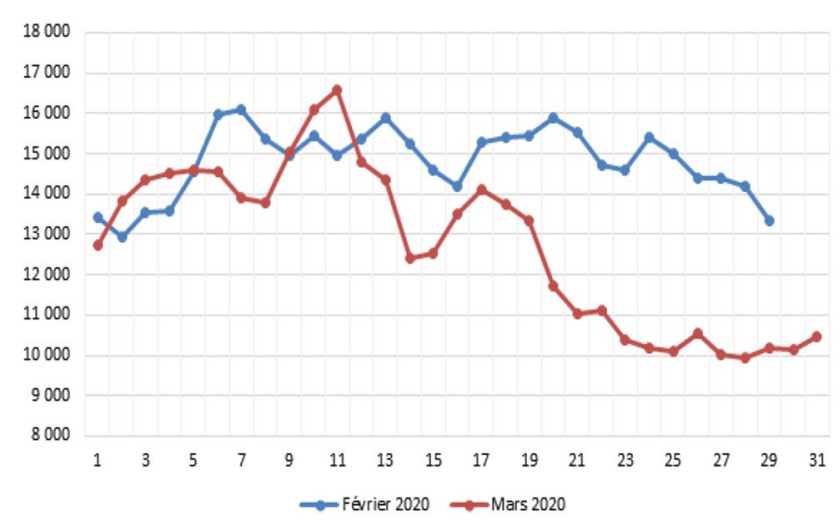

Fig. 11 Daily demand for natural gas (TEP) 


\section{References}

Anjum NA (2020) Good in the worst: COVID-19 restrictions and ease in global air pollution. Preprints 2020:2020040069. https://doi. org/10.20944/preprints202004.0069.v1

Belhedi A (2007) The spatial influence of Tunisian cities via the diffusion of innovative multi-site companies. Cybergeo Eur J Geogr. https://doi.org/10.4000/cybergeo.24872

Cadotte M (2020) Early evidence that COVID-19 government policies reduce urban air pollution. https://doi.org/10.31223/osf.io/nhgj3

Coccia M (2020) Factors determining the diffusion of COVID-19 and suggested strategy to prevent future accelerated viral infectivity similar to COVID. Sci Total Environ. https://doi.org/10.1016/j. scitotenv.2020.138474

Collivignarelli MC, Abbà A, Bertanza G, Pedrazzani R, Ricciardi P, Miino MC (2020) Lockdown for CoViD-2019 in Milan: what are the effects on air quality? Sci Total Environ. https://doi. org/10.1016/j.scitotenv.2020.139280

Dantas G, Siciliano B, França BB, da Silva C, Arbilla G (2020) The impact of COVID-19 partial lockdown on the air quality of the city of Rio de Janeiro, Brazil. Sci Total Environ 729:139085. https ://doi.org/10.1016/j.scitotenv.2020.139085

EPA (2010) Our nation's air: status and trends through 2010. https ://www.epa.gov/sites/production/files/2017-11/documents/trend s_brochure_2010.pdf. Accessed 11 Apr 2020

EPA (2014) AQI: a guide to air quality and your health. https://www3. epa.gov/airnow/aqi_brochure_02_14.pdf. Accessed 5 Apr 2020

Escudero M, Segers A, Kranenburg R, Querol X, Alastuey A, Borge R, de la Paz D, Gangoiti G, Schaap M (2019) Analysis of summer $\mathrm{O}_{3}$ in the Madrid air basin with the LOTOS-EUROS chemical transport model. Atmos Chem Phys 19:14211-14232. https://doi. org/10.5194/acp-19-14211-2019

He G, Pan Y, Tanaka T (2020) COVID-19, city lockdown, and air pollution: evidence from China. medRxiv. https://doi. org/10.1101/2020.03.29.20046649

IQAir (2020) COVID-19 air quality report 2019: coronavirus pandemic lockdowns result in unprecedented reductions in deadly particle pollution. https://www2.iqair.com/sites/default/files/documents/REPOR T-COVID-19-Impact-on-Air-Quality-in-10-Major-Cities_V6.pdf

Kerimray A, Baimatova N, Ibragimova O, Bukenov B, Kenessov B, Plotitsyn P, Karaca F (2020) Assessing air quality changes in large cities during COVID-19 lockdowns: the impacts of trafficfree urban conditions in Almaty, Kazakhstan. Sci Total Environ 730:139179. https://doi.org/10.1016/j.scitotenv.2020.139179

Lai C-C, Shih TP, Ko W-C, Tang H-J, Hsueh P-R (2020) Severe acute respiratory syndrome coronavirus 2 (SARS-CoV-2) and coronavirus disease-2019 (COVID-19): the epidemic and the challenges. Int J Antimicrob Agents 55:105924. https://doi.org/10.1016/j.ijant imicag.2020.105924

Lippi G, Sanchis-Gomar F, Henry BM (2020) Association between environmental pollution and prevalence of coronavirus disease 2019 (COVID-19) in Italy. medRxiv. https://doi. org/10.1101/2020.04.22.20075986

Ministère EMTE (2020) Ministère EMTE homepage. https://www. energymines.gov.tn. Accessed 5 Apr 2020
Nakada LYK, Urban RC (2020) COVID-19 pandemic: impacts on the air quality during the partial lockdown in São Paulo state, Brazil. Sci Total Environ 730:139087. https://doi.org/10.1016/j.scitotenv.2020.139087

National Statistics Institute (2014) General census of population and housing http://www.ins.tn/sites/default/files/publication/pdf/ vol\%201\%20rgph\%202014\%20\%281\%29.pdf. Accessed 30 Mar 2020

Otmani A, Benchrif A, Tahri M, Bounakhla M, Chakir E, El-Bouch M, Krombi M (2020) Impact of COVID-19 lockdown on PM 10 , $\mathrm{SO}_{2}$ and $\mathrm{NO}_{2}$ concentrations in Salé City (Morocco). Sci Total Environ. https://doi.org/10.1016/j.scitotenv.2020.139541

Reuters (2020) Coronavirus could trigger biggest fall in carbon emissions since World War Two. https://www.reuters.com/article/ushealth-coronavirus-emissions/coronavirus-could-trigger-bigge st-fall-in-carbon-emissions-since-world-war-two-idUSKBN21L 0HL. Accessed 7 Apr 2020

Sanità DTL, Bellini E (2020) Novel coronavirus: how atmospheric particulate affects our environment and health. Challenges 11:6. https://doi.org/10.3390/challe11010006

Sharma S, Zhang M, Anshika J, Zhang H, HarshaKota S (2020) Effect of restricted emissions during COVID-19 on air quality in India. Sci Total Environ. https://doi.org/10.1016/j.scitotenv.2020.138878

Shi X, Brasseur GP (2020) The response in air quality to the reduction of Chinese economic activities during the COVID-19 outbreak. Geophys Res Lett. https://doi.org/10.1029/2020GL088070

Shrestha AM, Shrestha UB, Sharma R, Bhattarai S, Tran HNT, Rupakheti M (2020) Lockdown caused by COVID-19 pandemic reduces air pollution in cities worldwide. https://doi.org/10.31223/osf.io/edt4j

Spinney L (2020) Epidemics expert Jonathan Quick: 'The worst-case scenario for coronavirus is likely'. The Guardian 1 Mar 2020. https://www.theguardian.com/world/2020/mar/01/the-worst-casescenario-for-coronavirus-dr-jonathan-quick-q-and-a-laura-spinn ey. Accessed 7 Apr 2020

Travaglio M, Yu Y, Popovic R, Selley L, Santos-Leal N, Miguel M (2020) Links between air pollution and COVID-19 in England. medRxiv. https://doi.org/10.1101/2020.04.16.20067405

Tunisian Ministry of Health (2020) Tunisian National Health Portal. https://www.santetunisie.rns.tn/fr/. Accessed 30 Mar 2020

Villeret G (2020) PopulationData.net homepage. https://www.popul ationdata.net/pays/tunisie/aires-urbaines. Accessed 11 Apr 2020

Wang P, Qiao X, Zhang $\mathrm{H}$ (2020) Modeling $\mathrm{PM}_{2.5}$ and $\mathrm{O}_{3}$ with aerosol feedbacks using WRF/Chem over the Sichuan Basin, southwestern China. Chemosphere 254:126735. https://doi.org/10.1016/j.chemo sphere.2020.126735

Wood AJ (2020) European air pollution in decline since COVID-19 lockdown. https://newseu.cgtn.com/news/2020-03-31/Europeanair-pollution-in-decline-since-COVID-19-lockdown-Pi2RASSiHu /index.html

World Bank (2020) The World Bank in Tunisia: overview. https:// www.worldbank.org/en/country/tunisia/overview. Accessed 30 Mar 2020

Worldmeters (2020) Country-specific coronavirus data. https://www. worldometers.info/coronavirus/?\#countries. Accessed $30 \mathrm{Apr}$ 2020

Zhao Y, Zhang K, Xu X, Shen H, Zhu X, Zhang Y, Hu Y, Chen G (2020) Substantial changes in nitrogen dioxide and ozone after excluding meteorological impacts during the COVID-19 outbreak in mainland China. Environ Sci Technol Lett 7:402-408. https:// doi.org/10.1021/acs.estlett.0c00304 


\section{Affiliations}

Nihel Chekir ${ }^{1}\left[\right.$ Yassine Ben Salem $^{1}$ (1)

$\bowtie$ Nihel Chekir

nihel.chekir@enig.u-gabes.tn; chekir.nihel@gmail.com

Yassine Ben Salem

yassine.bensalem@enig.u-gabes.tn;

yassinebensalem@ieee.org
1 National Engineering School of Gabes, University of Gabes, Gabes, Tunisia 